Syntax Literate : Jurnal Ilmiah Indonesia p-ISSN: 2541-0849

e-ISSN : 2548-1398

Vol. 5, No. 6, Juni 2020

\title{
ANALISIS FAKTOR-FAKTOR MEMPENGARUHI KINERJA PEGAWAI PADA DINAS PENDIDIKAN KABUPATEN CIREBON
}

\section{Triani Patra Pertiwi dan Andika Saputra}

Sekolah Tinggi Ilmu Ekonomi Cirebon

Email: triani@stiecirebon.ac.id dan andika@stiecirebon.ac.id

\section{Abstract}

To carry out its main tasks and functions staffing of education office of Cirebon is considered still not optimal. Low level of employee performance is shown to cause workload to be divided unevenly and is not compatible with tupoksi, and the lack of appreciation either in the form of money or non-money for employees who have work performance. Among the several things that can be done in developing employees are improving work ability self motivation and emotional intelligence development. Of course this must be based on awareness and carrying capacity of the organization. The contribution is given by the influence of motivational factors on Employee Performance can also be seen from the results of the t-count of the motivational factor variables (X2) 4,871 $\geq$ t_table (0,68137) with a level of significance $\alpha=5 \%$. While the contribution is given by the influence of the Capability Factor, on Employee Performance can be seen from the results of the tcount of the Capability Factor variable (X1) is 4,311 $\geq t$ tabel $(0,68137)$ with a level of significance $\alpha=5 \%$. Means there is a significant influence between the variable ability factors (X1) with Employee Performance (Y). From these results then Ho was rejected Ha was accepted. Then know that F-test the two independent variables are equal to 161,491 or there is a relationship because the Sig level is equal to 0,000 or smaller than 0,05 ( $p<0.05)$. which means that the variable ability and motivation factors together have a significant influence on employee performance. From these results Ho was rejected and Ha was accepted.

Keywords: Performance, Employees, Abilities, Influences, Awards.

\begin{abstract}
Abstrak
Untuk melaksanakan tugas pokok dan fungsinya Kepegawaian Dinas Pendidikan kabupaten Cirebon dianggap masih belum optimal. Rendahnya tingkat kinerja pegawai ditunjukan menyebabkan baban kerja menjadi terbagi tidak rata dan tidak sesuai pada tupoksi, dan kurangnya bentuk penghargaan baik dalam bentuk uang atau non uang bagi pegawai yang memiliki prestasi kerja. Diantara beberapa hal yang dapat dilakukan dalam mengembangkan diri karyawan adalah peningkatan kemampuan kerja, motivasi diri dan pengembangan kecerdasan emosional. Tentunya hal tersebut harus didasari atas kesadaran dan daya dukung dari organisasi. Kontribusi yang diberikan oleh pengaruh faktor motivasi dengan Kinerja Pegawai dapat juga kita lihat dari hasil Nilai thitung variabel Faktor motivasi (X2) sebesar 4,871 $\geq \mathrm{t}$ tabel $(0,68137)$ dengan tingkat signifikansi $\alpha=5 \%$. Sedangkan Kontribusi yang diberikan oleh pengaruh Faktor Kemampuan, terhadap
\end{abstract}




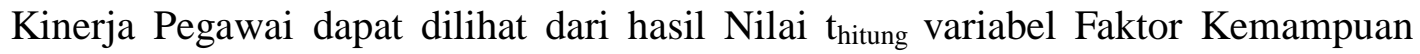
(X1) sebesar $4,311 \geq t_{\text {tabel }}(0,68137)$ dengan tingkat signifikansi $\alpha=5 \%$. Berarti terdapat pengaruh yang signifikan antara variabel Faktor Kemampuan (X1) dengan Kinerja Pegawai(Y). Dari hasil tersebut maka Ho ditolak dan berarti Ha diterima. Kemudian ketahui bahwa uji $\mathrm{F}$ kedua variabel bebas sebesar 161,491atau ada hubungan karena tingkat Sig sebesar 0,000 atau lebih kecil dari 0,05 $(\mathrm{p}<0.05)$ yang berarti variabel Faktor Kemampuan dan Faktor motivasi secara bersama-sama mempunyai pengaruh yang signifikan terhadap Kinerja Pegawai. Dari hasil tersebut maka Ho ditolak dan Ha diterima.

Kata Kunci: Kinerja, Pegawai, Kemampuan, Pengaruh, Penghargaan.

\section{Pendahuluan}

Aktifitas organisasi senantiasa membutuhkan peran manusia sebagai sumber daya agar mampu berkembang terus menerus, dengan demikian perkembangan yang terjadi akan mepengaruhi stabilitas dan konsistensi organisasi tersebut. Sumber daya manusia merupakan bagian penting dalam aktivitas kerja (Saridawati, 2018). Tuntutan masyarakat dalam dunia kerja akan adanya peningkatan efektifivitas kerja terhadap kinerja pegawai semakin kuat. Masyarakat sebagai pelaku utama dalam pelaksanaan pembangunan diharapkan dapat berperan aktif. Untuk itu perlu didukung dengan terciptanya sumber daya manusia yang memiliki modal kerja yang kondusif, yang ditandai dengan adanya fasilitas kerja yang layak dan dapat dipertanggungjawabkan. Pemerintah senantiasa memberikan bimbingan, pembinaan dan menyediakan fasilitas untuk pegawai guna menumbuhkan kinerja pegawai sesuai perundang-undangan yang berlaku. Faktanya tidak jarang masyarakat yang merasa tidak puas dengan kinerja pegawai yang tidak maksimal dalam bekerja. Hal ini disebabkan karena kesalahan dalam memilih atau menentukan sumber daya sehingga tidak mencapai tujuan manajemen yang tepat dan efektif.

Dinas Pendidikan Kabupaten Cirebon adalah sebuah instansi dibawah dibawah wewenang Pemerintah Provinsi Jawa Barat (PEMPROV) dan Kementerian Pendidikan Nasional. Dinas Pendidikan Jawa Barat mempunyai tugas merumuskan kebijakan operasional dalam bidang pendidikan dan memiliki sebagian kewenangan terkait dengan Dunia Pendidikan wilayah provinsi. Sub bagian Umum dan Kepegawaian adalah fasilitas penting dalam sebuah organisasi seperti Dinas Pendidikan Kabutapen Cirebon.

Masih adanya pegawai di Dinas Pendidikan Kabutapen Cirebon yang tidak menyelesaikan pekerjaan dengan tepat waktu, masih terdapat pegawai yang keluar masuk kantor pada jam-jam kerja untuk urusan pribadi yang dapat menghambat kerjasama dan mengganggu konsentrasi rekan kerja lainnya, sehingga pekerjaan tidak dapat diselesaikan sesuai waktu yang ditentukan, tidak hanya itu adanya keterbatasan pegawai dalam menguasai peralatan modern yang menyebabkan pegawai bekerja tidak sesuai tugas pokok dan fungsi pekerjaannya. Faktor lainnya berupa kurangnya penghargaan bagi pegawai yang berprestasi dalam bekerja. 
Secara umum, keadaan di atas didasarkan pada buruknya tiga aspek yaitu pola penyelenggaraan (ketatalaksanaan), sumber daya manusia, dan kelembagaan pelayanan publik di Indonesia (Syukri, 2015). Dalam rangka mengidentifikasi kinerja pegawai, maka perlu dilakukan pengkajian terhadap teori yang bersangkutan. Menurut (Gibson, 1996) terdapat beberapa variable yang mempengaruhi kinerja dan perilaku pegawai yaitu: variable psikologis, organisasi dan individunya sendiri. Ketiga kelompok variable tersebut berpengaruh terhadap kinerja personel. Perilaku yang mempengaruhi kinerja merupakan perilaku yang memiliki hubungan dengan tugas-tugas pekerjaan yang harus selesai guna tercapainya sasaran jabatan atau tugas.

\section{Metode Penelitian}

Penelitian yang dilakukan memiliki tujuan dalam mencari kebenaran dan memecahkan permasalahan atas apa yang diteliti. Demi tercapainya tujuan tersebut maka dibutuhkan metode yang relevan dan tepat. Menurut (Suliyanto, 2018) metode penelitian adalah: "Cara ilmiah untuk mendapatkan data dengan tujuan dan kegunaan tertentu".

Metode penelitian yang digunakan merupakan penelitian deskriptif kuantitatif dengan pendekatan survey. Metode survey digunakan dalam rangka memperoleh data dari tempat alamiah (bukan rekayasa), peneliti menumpulkan data secara langsung dengan cara menyebarkan kuesioner, melakukan wawancara terstruktur dan sebagainya.

Menurut (Sugiyono, 2017) teknik pengumpulan data adalah: "Langkah strategis dalam penelitian, karena tujuan utama penelitian adalah memperoleh data". Metode penelitian data yang digunakan dalam penelitian ini adalah:

1. Interview (Wawancara)

Peneliti melakukan wawancara kepada seluruh konsumen Kemitraan Intinusa Mitra Jaya untuk mendapatkan informasi tentang fenomenayang terjadi. Apabila ingin menemukan permasalahan yang harus di teliti, mengumpulkan data dan mengetahui lebih dalam responden penelitain maka dapat dilakukan dengan wawancara. Menurut (Sugiyono, 2017) teknik wawancara mampu dilakukan dengan cara terstruktur maupun tidak dan dapat dilakukan dengan tatap muka (face to face) atau dengan menggunakan telepon.

2. Kuesioner (Angket)

Teknik kuesioner yaitu teknik pengumpulan data dengan cara memberikan pertanyaan dan pernyataan tertulis kepada responden. Kuesioner merupakan Teknik yang efisien apabila peneliti mengetahui secara pasti variable yang akan diukur dan mengetahui apa yang bisa diharapkan dari responden yang cukup besar dan tersebar di wilayah yang luas. Kuesioner dapat berupa pertanyaan tertutup atau terbuka dan dapat diberikan kepada responden secara langsung.Dalam penelitian ini kuesioner langsung diberikan kepada konsumen Kemitraan Intinusa Mitra Jaya yang berada diberbagai wilayah.

3. Observasi

Menurut (Sugiyono, 2017) observasi yaitu "Teknik pengumpulan data yang digunakan apabila masalah yang diteliti berkenaan dengan perilaku manusia, proses 
kerja, dan gejala alam serta responden yang diamati tidak terlalu besar." Observasi dapat dibedakan menjadi dua yakni observasi partisipan dan observasi non partisipan. Observasi ini dilakukan dengan cara peneliti terlibat langsung dengan objek yang sedang diamati dalam kegiatan sehari-hari.

\section{Hasil dan Pembahasan}

Penelitian ini bertujuan mencari pengaruh antara variabel bebas dan variabel terikat. Dalam hal ini seberapa besar hubungan Faktor Kemampuan dengan Kinerja Pegawai, Faktor Motivasi dengan Kinerja Pegawai dan gabungan antara Faktor Kemampuan dan Faktor Motivasi dengan Kinerja Pegawai.

\section{Hubungan Faktor Kemampuan dengan Kinerja Pegawai pada Dinas Pendidikan Kabupaten Cirebon}

Kinerja Pegawai tidak lepas dari Faktor Kemampuan Kerja yang dimiliki oleh karyawan, seorang karyawan akan bekerja dengan maksimal apabila ia memiliki Faktor Kemampuan Kerja yang baik dan mau mentaati peraturanperaturan yang telah ditetapkan guna mencapai tujuan yang telah disepakati. Dan setelah melihat Nilai thitung variabel Faktor Kemampuan (X1) sebesar 4,311 $\geq$ t_tabel $(0,6813)$ dengan tingkat signifikansi $\alpha=5 \%$ ini artinya terdapat pengaruh yang signifikan antara variabel Faktor Kemampuan (X1) dengan Kinerja Pegawai (Y).

Dengan demikian dapat disimpulkan bahwa terdapat pengaruh positif dan signifikan Faktor Kemampuan Kerja terhadap Kinerja Pegawai di Dinas Pendidikan Kabupaten Cirebon. Hasil ini sama dengan faktor kemampuan kerja yaitu sikap menghormati, menghargai, patuh dan taat terhadap peraturan yang berlaku, baik yang tertulis maupun yang tidak tertulis serta sangggup menjalankannnya dan tidak mengelak untuk menerima sanksi-sanksi apabila ia melanggar tugas dan wewenang yang diberikan kepadanya. Hasil penelitian ini juga sejalan atau sama dengan hasil penelitian yang dilakukan oleh Resti Lufitasari, di mana hasil penelitiannya menunjukkan bahwa ada pengaruh Faktor Kemampuan kerja terhadap kinerja karyawan pada Dinas Pendapatan di Yogyakarta. Hal ini ditunjukkan dengan harga thitung 15,268 lebih besar dari ttabel sebesar 1,671. Berdasarkan hasil penelitian di atas dapat dilihat bahwa Faktor Kemampuan Kerja yang dimiliki karyawan sangat berpengaruh terhadap Kinerja Pegawai, oleh karena itu Dinas Pendidikan Kabupaten Cirebon harus selalu meningkatkan Faktor Kemampuan Kerja agar Kinerja Pegawai pada pasien semakin meningkat.

\section{Hubungan Faktor Motivasi dengan Kinerja Pegawai pada Dinas Pendidikan Kabupaten Cirebon}

Berdasarkan temuan empiris yang menunjukkan adanya hubungan yang signifikan Faktor Motivasidengan Kinerja Pegawai, maka hasil penelitian ini memberikan beberapa informasi, diantaranya: (1) Faktor Motivasi di Dinas 
Pendidikan Kabupaten Cirebon Cirebon. mempunyai hubungan yang berarti dengan Kinerja Pegawai, (2) dengan Faktor Motivasi yang baik ini merupakan salah satu cara untuk meningkatkan Kinerja Pegawai di Dinas Pendidikan Kabupaten Cirebon, serta (3) kontribusi yang diberikan oleh pengaruh Faktor Motivasi terhadap Kinerja Pegawai sangat baik. Ini dapat dilihat dari hasil nilai thitung variabel Faktor Motivasi(X2) sebesar 4,871 $\geq \mathrm{t}$ tabel $(0,68137)$ dengan tingkat signifikansi $\alpha=5 \%$. Berarti terdapat pengaruh yang signifikan antara variabel Faktor Motivasi(X2) dengan Kinerja Pegawai (Y). Dari hasil tersebut maka Ho ditolak dan berarti Ha diterima.

Berdasarkan nilai $\beta$ dan t_hitungdapat diketahui bahwa variabel yang berpengaruh dominan pada Kinerja Pegawai adalah pada variabel Faktor Motivasi dengan nilai $\beta(0,340)$ dan $t$ hitung $(4,871)$ yang lebih besar dibandingkan variabel yang lain dan juga nilai signifikansi t_hitungyang paling baik.

\section{Hubungan Faktor Kemampuan dan Faktor Motivasi dengan Kinerja Pegawai pada Dinas Pendidikan Kabupaten Cirebon}

Secara empiris, hasil penelitian ini mengidentifikasikan: (1) terdapat hubungan yang signifikan antara Faktor Kemampuan dan Faktor Motivasi dengan Kinerja Pegawai pada Dinas Pendidikan Kabupaten Cirebon, serta (2) Faktor Kemampuan dan Faktor Motivasimemiliki pengaruh terhadap Kinerja Pegawai pada Dinas Pendidikan Kabupaten Cirebon. Namun dari kedua variabel tersebut ternyata Faktor Motivasi merupakan variabel yang jauh lebih baik pengaruh dan hubungannya dengan Kinerja Pegawai. Hal ini dapat membuktikan dengan sistem manajemen yang baik maka pelayanan yang diberikan pun jauh lebih baik dan teratur. namun demikian Kinerja Pegawai pada Dinas Pendidikan Kabupaten Cirebon ini tidak hanya dipengaruhi oleh Faktor Kemampuan dan Faktor Motivasi saja, tapi ada faktor lain (epsilon), yang juga berpengaruh, yang tidak dikaji dalam penelitian ini.

\section{Kesimpulan}

Terdapat hubungan yang signifikan antara Faktor Kemampuan dengan Kinerja Pegawai pada Dinas Pendidikan Kabupaten Cirebon. Kondisi Faktor Kemampuan pada Dinas Pendidikan Kabupaten Cirebon mempunyai hubungan yang berarti dengan kualitas pelayanan. Kontribusi yang diberikan oleh pengaruh Faktor Kemampuan, terhadap Kinerja Pegawai dapat dilihat dari hasil Nilai thitung variabel Faktor Kemampuan (X1) sebesar 4,311 $\geq$ t_tabel $(0,68137)$ dengan tingkat signifikansi $\alpha=5 \%$. Berarti terdapat pengaruh yang signifikan antara variabel Faktor Kemampuan (X1) dengan Kinerja Pegawai(Y). Dari hasil tersebut maka Ho ditolak dan berarti Ha diterima.

Terdapat hubungan yang signifikan antara faktor motivasi dengan Kinerja Pegawai di Dinas Pendidikan Kabupaten Cirebon. Berdasarkan temuan empiris hasil 
penelitian ini memberikan beberapa informasi, bahwa faktor motivasipada Dinas Pendidikan Kabupaten Cirebon mempunyai hubungan yang berarti dengan kualitas pelayanan. Kontribusi yang diberikan oleh pengaruh faktor motivasi dengan Kinerja Pegawai dapat juga kita lihat dari hasil Nilai thitung variabel Faktor motivasi (X2) sebesar 4,871 $\geq \mathrm{t}$ _tabel $(0,68137)$ dengan tingkat signifikansi $\alpha=5 \%$. Berarti terdapat pengaruh yang signifikan antara variabel Faktor motivasi (X2) dengan Kinerja Pegawai (Y). Dari hasil tersebut maka Ho ditolak dan berarti Ha diterima. Dan berdasarkan nilai $\beta$ dan t_hitungdapat diketahui bahwa variabel yang berpengaruh dominan pada Kinerja Pegawai adalah pada variabel Faktor motivasi dengan nilai $\beta(0,340)$ dan t_hitung $(4,871)$ yang lebih besar dibandingkan variabel yang lain dan juga nilai signifikansi t_hitungyang paling baik.

Dari hasil uji F maka disini penulis dapat menyimpulkan bahwa Faktor Kemampuan dan faktor motivasi yang merupakan salah satu indikator untuk dapat memberikan Kinerja Pegawai yang baik pada pasien yang datang untuk meminta pertolongan. Dilihat dari hasil tabel diatas maka dapat kita ketahui bahwa uji F kedua variabel bebas sebesar 161,491 atau ada hubungan karena tingkat Sig sebesar 0,000 atau lebih kecil dari 0,05 ( $\mathrm{p}<0.05)$ yang berarti variabel Faktor Kemampuan dan Faktor motivasi secara bersama-sama mempunyai pengaruh yang signifikan terhadap Kinerja Pegawai. Dari hasil tersebut maka Ho ditolak dan Ha diterima. 
Triani Patra Pertiwi dan Andika Saputra

\section{BIBLIOGRAFI}

Gibson, James L. et al. (1996). Organisasi: Perilaku, Struktur, Proses (Terjemahan; Ninuk Adriani, ed.). Jakarta.

Saridawati. (2018). Pengelolaan Dan Pengembangan Sumber Daya Manusia Pada PT. Atmoni Shamasta Prezki. Syntax Literate ; Jurnal Ilmiah Indonesia, 3, No.9 Se, 107.

Sugiyono. (2017). Metode Penelitian Kuantitatif, Kualitatif, dan R\&D. Bandung: CV. Alfabeta.

Suliyanto. (2018). Metode Penelitian Bisnis untuk Skripsi, Tesis \& Disertasi. Yogyakarta: Andi Publisher.

Syukri, Agus Fanar. (2015). Tinjauan Sosio Teknologi Atas Penerapan Standar Pelayanan. (November). 